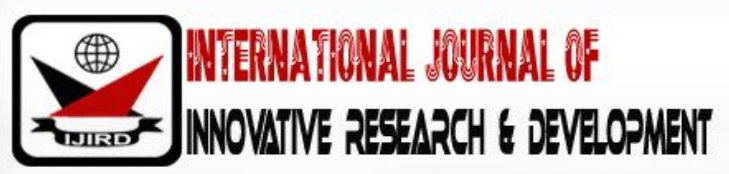

ISSN 2278 - 0211 (Online)

\section{Endemic Corruption and Challenges of Reforms and State Buildling in Nigeria}

\author{
Rev. Fr. Anthony Bature \\ Associate Professor, Federal University Wukari, Taraba state, Nigeria \\ Nebeife Chigozie Joseph \\ Lecturer, Political Science Department, Federal University Wukari, Taraba state, Nigeria
}

\begin{abstract}
:
With the end of World War II and consequent decolonization across the globe, developing countries have consciously pursued different measure in the form of socio-economic and political reforms targeted at state building. Such efforts have been confronted by several challenges which endemic corruption ranks topmost. This study is therefore set to examine how endemic corruption poses challenges to reforms and state building in Nigeria. The paper adopted documentary method and used descriptive analysis of secondary sources of data. The complex systems theory serves as the theoretical compass. The study uncovered that among other challenges of state building that endemic corruption appear to be responsible for failure of socio-economic and political reforms in Nigeria. The paper argued that apart from greed, the causes of corruption in Nigeria are not divorced from the lack of capacities of the institutions and structures of government to provide the basic necessities of life. The paper therefore recommended that the government should consciously build and develop the basic sectors including healthcare, education, housing and transportation as a mechanism for achieving meaningful development to overcome the complex problems associated with poverty and unemployment. This would drastically reduce corrupt tendencies and propel reforms and state building
\end{abstract}

Keywords: state building, corruption, reforms, development, leadership

\section{Introduction}

In view of the global rapid growth of democracy and liberalism as political ideologies and systems of governance, the State seems to have been recognized as a means to the welfare and the promotion of the collective good of the society (Mbah, 2007). The justification of the existence of States is undoubtedly premised on their capacities to provide public goods and services to persons living within its territory. To this end, the state is expected to demonstrate its ability and commitment to developing and sustaining infrastructure to meet socio-economic cum political needs of the people. Such include; healthcare, food, shelter, education, transportation, communication employment, liberty and political inclusiveness. The modern states focus and answer the concerns and demands of citizens by organizing and channeling the interests of their people, often but not exclusively in furtherance of national goals and values. The success or failure of States could be judged based on the levels of their effective delivery of the most crucial goods and services. The implication is that for state to remain valid and relevant, it must demonstrate the capacity and willingness to provide the needs of the society.

Since political independence of Nigeria in 1960, there has been several efforts aimed at bringing about reforms that could facilitate state-building for development. Such efforts aimed at improving the institutions and well-being of the citizens seem have been confronted by several challenges which endemic corruption ranks topmost. Evidently, the return to democratic rule in 1999, Nigeria seem to have been confronted with seemingly overwhelming incidences of corruption related cases. This seems to have defied the objective of establishing two major anti-graft agencies: Independent Corrupt Practices and Other Related Offences Commission (ICPC); and the Economic and Financial Crimes Commission (EFCC) to curb corruption in the country. Incidentally, corruption in Nigeria appear to have become endemic assuming the posture of a permanent feature of the Nigerian polity and almost institutionalized into the realm of culture and value system of the country (Nwanegbo \& Odigbo, 2015). The setbacks and probable failures in achieving socio-economic cum political reforms and state building in Nigeria is not divorced from the persistence of the monstrous cancer known as endemic corruption.

Undoubtedly, scholarly studies on corruption in Nigeria abound. Studies such as (Aiyede, 2009; Enweremadu, 2010; Umezurike, 2010; Nwanegbo \& Odigbo, 2015) have separately argued that corruption has been responsible for the shrinking economic condition of the Nigerian state. However, most of these studies seem to be inadequate in examining the impact of 
endemic corruption on reforms and state building in Nigeria. It is within this context that this paper examines the extent endemic corruption tends to impact on reforms and state-building in Nigeria. It looks at the challenges of state building with specific focus on the extent corruption impact on reforms targeted at improving institutions and structures for societal development.

\section{Theoretical compass- Complex Systems Theory}

Epistemological the Complex systems theory is rooted in the cybernetics theory and logic modeling where the focus is on the functional relations between the parts of a system, rather than the parts themselves, (Wiener, 1948). The theory emphasizes on how parts of a system give rise to the collective behaviors of the system, and how the system interacts with its environment (New England Complex Systems Institute, 2005). Complex systems consist of a mass mutually interacting parts that requires the understanding of the behavior of the parts to know how they act together to form the behavior of the whole (Bar-Yam, 1997, Rind, 1999). The interacting components in a complex system is large and there are multiple pathways by which the system can evolve (Whitesides \& Ismagilov, 1999).

Following from the above, endemic corruption has to do with institutionalized flagrant abuses of public office and resources for private or group gain, acts which are produced by specific political-economic processes happening in specific socio-cultural environments. In Nigeria, endemic corruption results from the malfunctioning of systems such as healthcare, education, transportation, housing amongst others. Nigeria is a complex society of multi-faceted diversities in ethnic, religion and culture. As a result, When the actors in a particular political and economic system struggle for power and wealth in a society where legitimacy of the system is in question, multiple motivations and opportunities that exist within the structure, propels corrupt practices. When corrupt practices are entrenched and normalized in the perception of the actors, there is erosion of systemic values and endemic corruption becomes the norm of the society.

In other words, people indulge in corrupt practice due to fear of uncertainties and the quest to remain above poverty lines and have unfettered access to the basic necessities of life. Such fears include job insecurity and dearth of resources for sustenance. Therefore, the explanation of endemic corruption and its impact on reforms and state-building in Nigeria is traceable to how it has been entrenched and sustained by the complex relations in the system as facilitated by motivations and opportunities that exists within the political system. The emergence and complexity of the systems, makes complex systems theory very suitable in explaining the trajectory that has sustained endemic corruption which hinders reforms and state building in Nigeria. Following from the above, the complex systems theory serves as the bedrock for our analysis of endemic corruption and challenges of reforms and state building in Nigeria.

\section{Conceptualizing Endemic Corruption, Reforms and State-Building}

Endemic corruption has to do with the act of institutionalizing corruption in the social, economic and political lives of a given society. In this sense, corruption assumes the posture of a culture and norms of the society. It is where corruption instead of being abhorred is elevated to the status of norm or pseudo identity of the society. Ordinarily, corruption refers to an arrangement that involves an exchange between two parties (the demander and the supplier) which has an influence on the allocation of resources either immediately or in the future. It is a deviation from formal rules and involves the use or abuse of public or collective responsibility for private ends, (Macrae, 1982; Khan,1996). According to Osoba (1996, p.6), "corruption is an anti-social behaviour conferring improper benefits contrary to legal and normal norms and which undermines the authorities' capacity to secure the welfare of all citizens".

Corruption is a betrayal of trust resulting directly or indirectly from the subordination of public goals to those of the individual. Thus, a person who engages in nepotism has committed an act of corruption by putting his family interests over those of the larger society (Gire 1999). In this regard, Otite (2000), argued that corruption is the perversion of integrity or state of affairs through bribery, favour or moral depravity. It takes place when at least two parties have interacted to change the structure or processes of society or the behavior of functionaries in order to produce dishonest, unfaithful or defiled situations. Corruption involves securing wealth or power through illegal means for private gain at public expense; or a misuse of public power for private benefit.

The manifestations and practice of corruption cut across all sectors including public, private, civil society amongst others. However, public sector corruption remains the more serious problem given the inevitable role of state in regulating other sectors of the society. The most common definition of corruption is the abuse of public office for private gain. It covers a range of actions including bribery, extortion, asset-stripping, and illicit influence. This definition suggests that gains may accrue to individuals or to groups, and that what is considered "abuse" may vary according to situations and settings regardless of whether it is legal or illegal. Several issues which are closely linked to corruption but distinct from it are clientelism and patrimonialism, rent-seeking, and organized crime, Hellman, Jones and Kaufmann, (2000).

In an elaborate analysis, Alatas (1990) divided corruption into seven distinct types: autogenic, defensive, extortive, inventive, nepotistic, supportive, and transitive. Autogenic corruption is self-generating and typically involves only the perpetrator. Defensive corruption involves situations where a person needing a critical service is compelled to bribe in order to prevent unpleasant consequences being inflicted on his interests. Extortive corruption is the behavior of a person demanding personal compensation in exchange for services. Investive corruption entails the offer of goods or services without a direct link to any particular favor at the present, but in anticipation of future situations when the favor may be required. 
Nepotistic corruption refers to the preferential treatment of, or unjustified appointment of friends or relations to public office, in violation of the accepted guidelines. The supportive type usually does not involve money or immediate gains, but involves actions taken to protect or strengthen the existing corruption. For example, a corrupt regime or official may try to prevent the election or appointment of an honest person or government for fear that the individual or the regime might be probed by the successor(s). Transactive corruption refers to situations where the two parties are mutual and willing participants in the corrupt practice to the advantage of both parties. For example, a corrupt business person may willingly bribe a corrupt government official in order to win a tender for a certain contract.

In which ever dimension corruption manifests, it has remained a chronic challenge to state building. Indeed, navigating these challenges called to mind the need for reforms. Reforming the sub-structure of the state is at the centre of the process of recovery. The reforms must first have a positive impact on the demand and address the national development and productive capacity building. Stimulating supply and demand is therefore an intermediate objective or a necessary transient point for any effective reform.

There seems to be no divergent opinions among scholars on what constitute state-building but what seems to vary in their submissions is how a state can be built and who drives the process. Thus, issues on when and who drives the entire process of building a state appear to have made the understanding of the concept to be more complex. Scholars such as (Fritz $\&$ Menocal, 2007; Whaites, 2008) have separately posited that state-building can be seen as strengthening the capacity of state by both national and international actors. More specifically, state-building refers to the set of actions undertaken by national and/ or international actors to reform and strengthen the capacity, legitimacy and the institutions of the state where these have seriously been eroded or are missing (Fritz \& Menocal 2007, p.13I). For them, the focus of state building should not be merely about 'top-down' approaches of institution strengthening (i.e. focusing on state actors and/ or national elites) but about bottom-up' approaches as well, i.e. linking state and society by working through the citizens and civil society (Menocal 2011). In fact, State building is based on three dimensions which consist of a security dimension, a political dimension, and an economic dimension.

Whaites, (2008) opined that state building entails the process through which states enhance their ability to function. The goals of this so-called 'functionality' will vary as they may be influenced by factors such as government priorities and may or may not put emphasis on areas orientated to the public good. Therefore state-building is a value neutral term; it takes place in all states, whether they are rich or poor, resilient or fragile. All states are trying to improve their structures and increase their capacities. State-building is a national process. According to Fritz \& Menocal, (2007) the key goals of state-building include provision of security, establishment of the rule of law, effective delivery of basic goods and services through functional formal state institutions, and generation of political legitimacy for the (new) set of state institutions being built. Ensuring the quality and integrity of government is an important dimension of the state-building process as state-building is inherently a dynamic and ongoing processes.

There are different models and approaches to state-building. This perhaps explains why some states manage statebuilding better than others. There are particularly two contrasting models that show the complexity. The Responsive model posits that state-building does not occur at a certain stage of development, instead it is a result of an extensive range of policy and non-policy factors that can occur in any state. Responsive model of state-building involves three compulsory areas of progress; political settlement, survival functions, and expected functions (Whaites 2008,). In order for a responsive statebuilding to occur political settlements are crucial and must absorb social change. The second required area of progress for responsive state-building is a set of core functions essential to the survival and strength of the institutional framework of the state, (Whaites 2008).

Whaites further stressed that all responsive state-building processes must develop capacity in relation to three areas; security (to be able to control the use of violence), revenue (raise funds, particularly through taxation), and law (the capability to rule through laws) (Whaites 2008, p. 8). The third and the last area of essential progress is the realization of an "expected" level of functionality. Expected functions sees responsive states trying to keep up with the demands and the provision of basic goods and services (Whaites 2008, p. 9). These expectations are in other words about responsive governments attempting to perform on issues that are important to the citizens and external actors, (Whaites 2008, p. 12).

On the other hand, Unresponsive model of state-building refers to a situation where political settlements can cause ineffective, oppressive and corrupt (unresponsive) states. It is emphasized here that settlements rely on satisfying the selfinterest or core beliefs of elites that they belong to, and the reason of unresponsive state-building is often the need to keep powerful constituencies on board, (Whaites, 2008). The nature and character of the state structures and political rules can make the unresponsive state-building worse. An institutional structure for politics that is poorly designed can make the process and development of a political settlement more problematic.

Furthermore, a problem that is for the most part prominent in unresponsive state building is the question of culture and ideology. A number of political settlements may be driven by an ideological or religious vision for the state and nation that hastens the capacity building of some state-structures, but at the same time places restrictions on the way in which the state will respond to public expectations. This implies that there could be periods of stability in unresponsive state-building as well, but these states will remain weak to significant problems of the society. Many states will show signs of both responsive and unresponsive state-building, often as a result of geographical and historical legacies. The discussion of both these two models 
shows that the nature of the political settlements is vital to the effectiveness of the state and its functionality. In order to understand state-building one has to understand how governments are formed and operate, (Whaites 2008).

The goals of tackling hunger, poverty and unemployment, provision of security, establishment and enforcement of the rule of law and effective delivery of basic goods and services through functional formal state institutions should be paramount in state building, (Fritz \& Menocal, 2007). Others also comprises of the capacity to generate political legitimacy for the (new) set of state institutions being built predicated on certain principles. In other words, the fundamental principles of state building revolve around Credible elections, inclusiveness, transparency, Rule of Law, ethical Conduct, Competence and Capacity, Innovation and Openness to Change. It also includes, sustainability and Long-term Orientation, Sound Financial Management, Human rights, Cultural Diversity and Social Cohesion, Accountability etc.

There should be an honest attempt to mediate between various legitimate interests and to reach a broad consensus on what is in the best interest of the whole society and on how this can be achieved. Decisions are taken according to the will of the many, while the rights and legitimate interests of the few are respected. The state must be responsive enough to the extent that the necessary objectives, rules, structures, and procedures are adapted to the legitimate expectations and needs of citizens. Public services must be delivered, and requests and complaints are responded to within a reasonable timeframe. The principle of efficiency and effectiveness emphasizes that results should meet the agreed objectives. It is making the possible best use of available resources.

The public good must be placed above individual interests. There must effective measures to prevent and combat all forms of corruption. Conflicts of interest should be declared in a timely manner and persons involved must abstain from taking part in relevant decisions. The professional skills of those who deliver governance should be continuously maintained and strengthened in order to improve their output and impact. Public officials need to be motivated to continuously improve their performance. Practical methods and procedures are to be created and used in order to transform skills into capacity and to produce better results. New and efficient solutions to problems must be sought and advantage is taken of modern methods of service provision. The needs of future generations should be taken into account in current policies. There should be a broad and long-term perspective on the future of the society along with a sense of what is needed for such development. Implicitly, charges should not exceed the cost of services provided and do not reduce demand excessively, particularly in the case of important public services.

Human rights must be respected, protected, and implemented, and discrimination on any grounds should be combated. Cultural diversity has to treated as an asset, and continuous efforts are made to ensure that all have a stake in the country, identify with it and do not feel excluded. Social cohesion and the integration of disadvantaged areas need to be promoted. Access to essential services is preserved, in particular for the most disadvantaged sections of the population. All decision-makers, collective and individual should take responsibility for their decisions. There must be an effective remedy against maladministration and against actions of the authorities which infringe civil rights.

\section{Endemic Corruption and Challenges of Reforms and State Building in Nigeria}

Unarguably, the task of engaging in meaningful reforms and effective state-building is often more daunting than the achievement of political independence. This can easily be seen from the challenges posed by endemic corruption in fraughting the process of reforms and state building. It is evident that endemic corruption weakens the ability of the State to promote good governance, fairness and social justice and thus entrenches poverty and inequality, (Anderson and Tverdova, 2003; Gupta, 1995). Corruption has coexisted with human society for a long time and remains as one of the problems in many of the world's developing economies with devastating consequences on state building and development. Corruption has to do with efforts to secure wealth or power through illegal means for private gain at public expense; or a misuse of public power for private benefit. Corruption as a phenomenon, is a global problem, and exists in varying degrees in different countries (Agbu, 2001).

Corruption is not only found in democratic and dictatorial politics, but also in feudal, capitalist and socialist economies. Christian, Muslim, Hindu, and Buddhist cultures are equally bedeviled by corruption (Dike, 2005). Corrupt practices are recent issues; but the history is as old as the world (Lipset \& Lenz, 2000). It is the cankerworm that seem has eaten deep into the fabrics of many countries and had stunted growth in almost all the sectors thereby distorting societal reforms and hindering state building especially in Nigeria. It tends to discourages foreign investment and depletes the resources available for economic development and infrastructure, (Wei, 2000). Due to the prevalence of endemic corruption, there is unnecessary increases in the cost of public investment, erosion of the capacity of the government to extract taxes, thus reducing government revenues and quality of public infrastructure, (Campos \& Pradhan, 1999.

Corruption depletes funds from state budgets that should be applied for the development of infrastructures and basic amenities. It tends to undermine the fairness of institutions and processes and distorts policies and priorities of state building. To a larger extent, corruption dents the legitimacy of regimes leading to a loss of public support and trust for state and government institutions. Corruption impacts on the ability of the State to fulfill its core obligations and to deliver relevant services, including a functioning judiciary, law enforcement amongst others. In Nigeria, corruption seem to have pervaded the various levels of government and all strata of legal systems thereby impeding necessary legal reforms and the fair administration of justice. It leads to erosion of accountability and transparency in public institutions. The most worrisome is that corruption hampers the right of indigenous peoples to participate in decisions related to natural resource extraction. 
Corruption seem to have the tendency to retard the necessary reforms required for state building. According to Eigen (2001) corruption is seen as a daunting obstacle to state building and sustainable development. Indeed, it is a constraint on education, health care and poverty alleviation, and a great impediment to socio-economic and political reforms in Nigeria. Agbu (2001) posited that corruption affects the behaviour of public and private officers who improperly and unlawfully enrich themselves or those closely related to them, or induce others to do so, by misusing their privileged positions. This is known as endemic systemic corruption which occurs where bribery (money in cash or in kind) is taken or given in a corrupt relationship. These include kickbacks, pay-off, sweeteners, greasing palms, etc) on a large or small scale. Indeed, corruption is a significant social and ethical problem that has an important impact on all societies. It is a phenomenon that exists in many countries and constitutes a problem for reforms and state building.

Thus, Otite (2000) identified some factors as instrumental to enthroning corrupt practices in most countries. These according to him, include the weak institutions of government, dysfunctional legal system, absence of clear rules and codes of ethics, low civil service salaries and poor working conditions and culture of impunity in governance.

Additionally, it could be argued that the fundamental factors propelling corruption in Nigeria has to do with unmitigated fear and anxiety among many Nigerians. These are orchestrated by high level of uncertainty due to dearth of infrastructure and functional institutions. In other words, perceived insecurity for access to basic amenities of life such as healthcare, education, housing and transportation tend to engender corruption in Nigeria. This entails that people indulge in corruption to amass wealth that can guarantee them regular access to these basic necessities of life. As a result, Nigeria has always been rated very high among the globally most corrupt nations by the Transparency International. The table below shows that between 1996 and 2017 the Transparency International has rated Nigeria high among most corrupt countries of the world.

\begin{tabular}{|c|c|c|c|}
\hline Year & Score & Position & $\begin{array}{c}\text { Total Number of Most } \\
\text { Corrupt Nations Surveyed }\end{array}$ \\
\hline 1996 & 0.6 & 54 & 54 \\
\hline 1997 & 1.7 & 52 & 52 \\
\hline 1998 & 1.9 & 81 & 85 \\
\hline 1999 & 1.6 & 98 & 99 \\
\hline 2000 & 1.2 & 90 & 90 \\
\hline 2001 & 1.0 & 90 & 91 \\
\hline 2002 & 1.6 & 101 & 102 \\
\hline 2003 & 1.4 & 132 & 133 \\
\hline 2004 & 1.6 & 144 & 145 \\
\hline 2005 & 1.9 & 152 & 158 \\
\hline 2006 & 2.2 & 142 & 179 \\
\hline 2007 & 2.2 & 147 & 180 \\
\hline 2008 & 2.7 & 121 & 180 \\
\hline 2009 & 25 & 130 & 180 \\
\hline 2010 & 24 & 134 & 178 \\
\hline 2011 & 24 & 143 & 182 \\
\hline 2012 & 27 & 139 & 176 \\
\hline 2013 & 25 & 144 & 177 \\
\hline 2014 & 27 & 136 & 174 \\
\hline 2015 & 26 & 136 & 170 \\
\hline 2016 & 28 & 136 & 176 \\
\hline 2017 & 28 & 148 & 180 \\
\hline
\end{tabular}

Table 1: Nigeria's Corruption Perception Index by Transparency International from 1996 to 2017

Source: (Adapted from Nwanegbo \& Odigbo (2015) with Few Modifications Using

Data from Transparency International Website)

The above report indicates that the Nigeria has not made meaningful progress in its fight against graft, despite the heavy presence of federal agencies and claims by the Muhammadu Buhari Presidency that it is making a headway. Evidently, in the 2017 rankings, Nigeria scored 28. In 2016, it scored 26 and in 2015, it scored 25. In 2014, the country scored 27 and 25 in 2013. In 2012, the country's score was 27 out of 100. It is thus obvious that Nigeria moving too slowly in its anti-corruption efforts within the past six years. This is undoubtedly a big blow to the President Muhammadu Buhari administration's anticorruption war. Although the administration has seized assets of politicians and government officials, it has also been accused of being partial in curbing corrupt practices by top government officials. This has a damaging effect on the efforts at state 
building and reforms in the Nigerian society. Apart from endemic corruption, other challenges of reforms and state building in Nigeria include but not limited to the following:

\subsection{Socio-Economic Inequalities}

An important aspect of nation-building is the building of a common citizenship. Through the development of the economy and equal opportunities for all, nations try to establish a base-line of social and economic rights which all members of the national community must enjoy. Not to enjoy these socio-economic rights means that the people involved are marginalized from national life. That is why in many Western European countries, contemporary State-building is about preventing 'social exclusion' or the exclusion of significant segments of the population from enjoying basic social and economic rights.

In Nigeria, not only are many of our citizens denied basic rights such as the right to education and health, there is also serious variation in the enjoyment of these rights across the country. As a consequence, the citizens are not motivated to support the state and society, because they do not feel that the society is adequately concerned about their welfare. Also critical is the fact that socio-economic inequalities across the country fuels fears and suspicious which keep our people divided. Inequalities pose a huge threat to a common citizenship, it breeds poverty and impedes on state building. A largely marginalized citizenry, increasingly crippled by poverty and the lack of basic needs, can hardly be expected to play its proper role in the building and development of the state. States are built by healthy and skilled citizens on grounds of both equity and efficiency and any country that desires to build the state needs a social contract with its citizens as a basis for demanding their loyalty and support.

\subsection{The Constitutional Challenge}

Constitution is known globally as the purveyor of laws of the society through which rule of law manifests. A constitutional challenge occurs where there is discordant among the people on the nature and form of government to be adopted. The people could decide to adopt and operate a democratic system of government by forming of government based on the will of the majority, respect for the rule of law, and respect for basic freedoms of citizens. Such arrangement could engender accountability and respect for the rule of law, or the holding of elections which promotes political system as an anchor for state-building. Where the constitution is flouted, tempering with liberty and freedom of the people, state building is jeopardized. The Nigerian constitution seems to flawed in several ways and apparently incapable of engendering social cohesion needed for reforms and state building.

\subsection{The Challenge of Leadership and Building Institutions}

Leadership Is a Critical Factor in state building as standards for recruitment and the performance of the individual leaders pose a big challenge to state building. Such leaders are those who do not understand the economic and political problems of the country, not to talk of finding durable solutions for them. They are more interested in silencing their opponents, than in pursuing justice and place themselves above the constitution and the laws of the country. For Nigeria to succeed in state-building, there must be a leadership that is committed to the rule of law and has a demonstrable sense of fair play and democratic tolerance; a leadership with ability and integrity. Another challenge facing Nigeria is that of institution building. The components of institution building consist of setting the rules; recruiting persons with the technical expertise and moral competence to interpret the rules or implement the goals of the organizations; and ensuring that the institutions inspire public confidence by being transparent, fair and consistent. In this regard, countries are required to create or strengthen institutions that would help achieve the national goals of democratic governance and sustainable development. The experience in Nigeria has shown weak and fragile institutions. It creates a situation where there are powerful personalities manipulating weak institutions thereby hindering necessary reforms and state building.

\subsection{The nature and character of the Nigerian state}

Looking at the character of Nigerian state, Adejumobi, (2006), averred that the several decades of military rule bequeathed the Nigerian political landscape with powerful "godfathers" who sit atop vast patronage networks at local, state and federal levels tends to impede reforms and state-building. To this end, political outcomes are primarily a function of titanic struggles among these magnates, who bargain among themselves and at the expenses of the impoverished greater public, within a political context of multiple ethno-religious and cultural divides. To this end, Alavi (1974) stated that the Nigerian state seem to be equipped with a powerful bureaucratic-military apparatus and mechanisms of government which enable them through its routine operations to subordinate the native social classes. Having inherited the overdeveloped apparatus of state and its institutionalized mechanisms for regulating the operations of indigenous social classes, the state appears to be enmeshed in deep crisis from which it can hardly extricate itself without fundamentally altering the existing statusquo. This breeds endemic corruption and thus hinders reforms and distorts state building.

\section{Conclusion/ Recommendations}

In this paper, we have examined how endemic corruption hampers reforms and impedes on state building. It is based on this that we conclude endemic corruption has been responsible for the failure of reforms and state building thereby 
perpetuating fragility of the Nigerian state. This is because corruption has a significant negative impact on reforms and undermines state building. Reforms and state-building therefore require institutional pluralism and independent institutions, evident in independent judiciary, an impartial public service, an effective parliament and a vibrant civil society. IT is therefore, recommended that political leaders should imbibe the principle of good governance, accountability and transparency in their dealings with public property and funds, in accordance with international best practices. It calls for formulation of sound policies that will drive domestic economic reforms with a view to enhancing efficiency and higher productivity growth; transparent and accountable governance. Instead of resorting to the divisive politics of indigene against settler as a means of accessing resources, a generalized commitment to social citizenship will create a civic structure of rights that will unite people around shared rights and goals. The fight against corruption should include moral education, values and norms of society which play an important role. Also, mechanisms should be established to observe and make responsible the individuals who have abused the laid rules and processes.

\section{References}

i. Adejumobi, S. (2006). "Do votes count? The travails of electoral politics in Nigeria" inAfrica Development, Vol. XXXI, No. 3.

ii. Agbu. O. (2003). Corruption and Human Trafficking: the Nigerian case. West Africa Review

iii. Alatas, H. (1990). Corruption: its nature causes and functions. Kuala Lumpur: S. AbdulMajeed and Co.

iv. Alavi, H. (1974), The State in Post-Colonial Societies. New Left Review, 74, July/ Augustpp. 59-81.

v. Anderson, C. \& Tverdova, Y. (2003). Corruption, political allegiances, and attitudes toward government in contemporary democracies. American Journal of Political Science, Vol.47, 91-109.

vi. Aiyede, E. (2009). The Political Economy of Fiscal Federalism and the Dilemma of Constructing the Developmental State in Nigeria, International Political Science Review, 30 (3): 249-269.

vii. Bar- Yam, Y. (1997). Dynamics of complex systems. Reading, MA: Perseus Books

viii. Campos, J. \& Pradhan, S. (1999). The impact of corruption on investment: Predictability matters. World Development, 27, 1059-1067.

ix. Dike, V. (2005). Corruption in Nigeria: A New Paradigm for Effective Control. Africa Economic Analysis. Retrieved on 1st August 2007 from http:/ / www.jsdafrica.com/Jsda/ Summer1999/ articlespdf

x. Eigen P. (2001). Global Corruption Report 2001. Transparency International edited by RobinHodess, Jessie Banfield and Toby Wolfie

xi. Enweremadu, D. (2010). Why Do Some Corrupt Regimes Promote Economic Development?Nigeria and Indonesia in Comparative Perspective. Being a Paper Delivered at the Departmental Seminar Series organized by the Department of Political Science, University of Ibadan, April 28.

xii. Fritz, V. and Menocal R. (2007) 'Understanding State-Building from a Political EconomyPerspective: An Analytical and Conceptual Paper on Processes, Embedded Tensions and Lessons for International Engagement', report prepared for DFID's Effective and Fragile States Teams, Overseas Development Institute.

xiii. Gire, J. (1999): A Psychological Analysis of Corruption in Nigeria. Journal of SustainableDevelopment. Retrieved 20th April2007ttp:/ / www.jsdafrica.com/Jsda/ Summer1999/ articlespdfARC\%20\%20A\%20Psychological\%20Analysis\%2 0of\% 20Corruption\%20in\%20Nigeria.pdf International Center for Economic Growth (1999). ICEG Information Brief 6, Causes and Effects of Corruption, Nairobi, 1999.

xiv. Gupta, A. (1995). Blurred boundaries: the discourse of corruption, the culture of politics, and the imagined state. American Ethnologist, Vol. 22, 375-402.

xv. Kaufmann, D. (2000). Seize the State, Seize the Day: State Capture, Corruption and Influence in Transition. World Bank Policy Research Working Paper 2444 (Sept 2000).

xvi. Khan, M. (1996): "A Typology of Corrupt Transactions in Developing Countries" IDSBulletin.

xvii. Lipset, S. and Lenz, G. (2000). Corruption, Culture, and Markets, in Culture Matters,

xviii. Macrae, J. (1982). Underdevelopment and the Economics of Corruption: A Game TheoryApproach. World Develop. 10(8): 677-687.

xix. Mbah, C. (2007). Foundations of political science. Anambra: Rex Charles \& Patrick ltd.

xx. New England Complex Systems Institute. (2005). What is the study of complex systems?[Online]. Available: http:/ / necsi.org/ guide/ whatis.html

xxi. Nwanegbo, J. \& Odigbo, J. (2015). Governance, Corruption and Crisis of Development in Post-Independence Nigeria, African Journal of Politics and Society, 1 (1): 24-44.

xxii. Osoba, S. (1996). Corruption in Nigeria: Historical Perspectives. Rev. Afr. Pol. Econ. 23(69): 371-386.

xxiii. Otite, O. (2000). "Corruption against the Norms of African life" in O. Femi (ed.) "Effective and efficient Implementation of Nigeria's Recent Anti-corruption legislation.

xxiv. Rind, D. (1999), Complexity and climate. Science. Unpublished paper. [Online]. Available:www.colorado.edu/ibs/ PEC/ johno/ pub/istanbul_moscow.pdf

xxv. Umezurike, C. (2010). State and Economy in Nigeria: A Study of Democracy and Economic Reform in the $4^{\text {th }}$ Republic. Enugu: Snaap Press Ltd 
xxvi. Whaites, A. (2008) 'State in Development: Understanding State-building', A DFID Working Paper.

xxvii. Wei, S. (2000). Natural openness and good government. NBER Working Paper 7765.

xxviii. Wiener, N. (1948). Cybernetics. Boston: MIT Technology Press.

xxix. Whitesides, G. and Ismagilov, R. (1999). Complexity in chemistry. Science, 284, 89-92. 